\title{
THIRD PARTY CHILD-CENTRED DISPUTES: PARENTAL RIGHTS V. BEST INTEREST OF THE CHILD
}

\author{
M. JOYCE SCHLOSSER*
}

\begin{abstract}
The author opens by defining and discussing the two competing approaches to third party child-centred disputes. She then goes on to place the discussion in context by examining the relevant British and Canadian case law and reviewing the pertinent legislation. She concludes by offering criticism and recommendations for reform.
\end{abstract}

\section{INTRODUCTION}

Child-centred disputes are not a recent phenomenon; since King Solomon's time they are known to have challenged the wisdom of judges and legislators. ${ }^{1}$ If not new, they are of ten controversial. Nothing arouses public sentiment like a bitter courtroom tug-of-war over an innocent child-victim. This is especially true in a third party dispute if one of the parties is a government department or publicly funded welfare agency and the case vividly illustrates an ancient political debate; that is, the proper limits of government intervention in family matters. ${ }^{2}$

In three millenia the real issues have changed so little that jurists still debate the wisdom of Solomon's judgment and continue to cite his case both in support and in refutation of the principles applied by modern courts to custody disputes. ${ }^{3}$ Of these principles, the two most important are the best interest of the child test and the parental rights doctrine. The former applies when the parents of a child compete for custody, a situation which arises most frequently in cases of divorce or separation. ${ }^{4}$ However when the conflict involves one or both parents and a third party, there is considerable disagreement on the appropriate principle.

Each of the principles may be said to represent one side in the debate on state intervention. The use of the best interest test facilitates state and

1. 1 Kings 3:23-27 (Revised Standard Version)

Then the king said, "The one says, 'This is my son that is alive, and your son is dead'; and the other says, 'No; but your son is dead and my son is the living one." " And the king said, "Bring me a sword." So a sword was brought before the king. And the king said, "Divide the living child in two, and give half to the one, and half to the other." Then the woman whose son was alive said to the king, because her heart yearned for her son, "Oh, my lord, give her the living child, and by no means slay it." But the other said, "It shall be neither mine nor yours; divide it". Then the king answered and said, "Give the living child to the first woman and by no means slay it; she is its mother."

2. An example is the recent B.C. case of Stephen Dawson which received nation-wide publicity. However, even when the competing claimants are private parties, the case may attract attention as did Re Moores and Feldstein, infra, n. 28, discussed by Weiler and Berman in a case comment, infra, n. 35 and the very recent Woods v. Racine 19 Man. R. (2d) 186 (C.A.). A report of the Supreme Court of Canada decision in the latter was carried in the October 14, 1983 National Edition of the Globe and Mail.

3. See for example, Comment, "Best Interests of the Child: Maryland Child Custody Disputes" (1977-78) 37 Maryland Law Review 641; P.L. Strauss and J.B. Strauss, Book Review: "Beyond the Best Interests of the Child" (1974) 74 Columbia Law Review 996; H.H. Foster "A Review of Beyond the Best Interests of the Child" (1975) 12 Willamette Law Journal 545; J.G. Gremillian, "Louisiana Child Custody Disputes Between Parents and Non-Parents" (1979) 25 Loyola Law Review 71; Notes and Comments, "Alternatives to 'Parental Right' in Child Custody Disputes Involving Third Parties" (1963-64) Part I, 73 Yale Law Journal 151 .

4. McKeev. McKee[1951] 1 All E.R. 942, [1951] 2 D.L.R. 657. 
court intervention while the doctrine of parental rights, in theory and in practice, restricts it. Therefore, the choice by legislators and judges of the principle to be applied in these cases assumes an importance beyond that related to immediate consequences for individuals in particular cases. Unfortunately the wider implications of ten go unrecognized.

An attempt will be made here to discuss the two principles and the types of third party disputes in which they apply; explain their incompatibility; trace a brief history of their use in English and Canadian case law and their presence in current Canadian legislation; criticize the more popular best interest test; and finally, recommend the use of a parental rights doctrine in those cases where government intervention occurs and a modified best interest test in private party matters.

\section{THE TWO COMPETING PRINCIPLES}

\section{A. TYPES OF DISPUTE}

\section{Child Protection}

There are three main types of third party child-centred disputes: child protection; adoption; and private party. A government department or child care agency or society is usually, although not necessarily, involved in cases of the first two types. The third is, by definition, limited to private parties.

A question of custody 5 typically arises in a child protection situation when an agency removes a child from parents whose conduct or circumstances, in its estimation, threaten the welfare of the child. The parents object to the apprehension of the child or appeal a court's removal order. In both cases a court must then decide whether the parents or the agency shall have custody. ${ }^{6}$

\section{Adoption}

In cases of adoption the difficulty usually occurs when a third party wishes to adopt a child whose natural parents either refuse to consent ${ }^{7}$ to the extinguishment of their rights vis à vis the child or withdraw their previous consent. ${ }^{8}$ They launch an action to prevent the adoption and to gain custody. The prospective adoptive parents and the agency involved argue that the case is an appropriate one for dispensation of the statutorily required consent and that the adoption should proceed. In the alter-

5. The term "custody" is used in this paper in its wide and more usual sense as almost the equivalent of guardianship in its fullest sense. As such, it embraces a "bundle of powers" including the power to exercise physical control until the age of discretion, to control education and choice of religion, etc. See Hewer v. Bryant [1970] 1 Q.B. 357 at 372-373. When disputes about children arise in the contexts of child protection and adoption, they may concern even more than this custody. In fact, legal rights to remain as parent and child may be at stake. Although the actual issue may be more, the term custody is used in this paper as a kind of "lowest common denominator" description of the various disputes.

6. See for example, Re Brown 9 O.R. (2d) 185 (Co. Ct.); Re Sarty 15 N.S.R. (2d) 93, 19 R.F.L. 315 (S.C.).

7. Lutz and Lutz v. Legal Aid Manitoba and Legal Aid Services of Manitoba 37 A.R. 351 (C.A.).

8. Hepton and Hepton v. Maat and Maat [1957] S.C.R. 606, 10 D.L.R. (2d) 1. 
native, they may ask the court, if it is not prepared to grant the adoption order without consent, to award at least custody to the would-be adoptive parents.

\section{Private Party}

The third type of conflict concerns only private parties. Typically, the natural parents of a child have separated or divorced and the custodial parent has subsequently died, leaving the child in the care of a third party. The surviving parent tries to obtain custody of the child from this third party. The court must decide between the natural parent who seeks custody and the third party who currently enjoys it. ${ }^{9}$

\section{B. JURISDICTION}

1. The Inherent Jurisdiction - the parens patriae power.

In Canada, various courts have jurisdiction in areas of family law in which child-centred disputes may arise. Jurisdiction is derived from either one or both of two sources: provincial legislation and an inherent jurisdiction inherited from the English High Court.

As regards the latter, at common law, courts were loath to interfere with the near-absolute rights of a father (and later the mother by legislation) to the custody of his legitimate children. ${ }^{10}$ The courts of equity, however, derived from the prerogative power of the crown as parens patriae, ${ }^{11}$ the jurisdiction to intervene between parent and child in the interest of protecting the child. This power, which at one time had been exercised by the Lord Chancellor, passed from the Court of Chancery to the High Court under the Judicature Act of $1873^{12}$ when in 1875 the Court of Chancery and the old common law courts were abolished. The new court was given the power to administer both law and equity ${ }^{13}$ and with their union, in cases of conflict or variance, the rules of equity prevailed in child custody matters. ${ }^{14}$ In Canada, this equitable jurisdiction resides in the various superior, district and county courts. ${ }^{15}$ The Alberta Court of Appeal has held that a superior court cannot, without express legislative action, be divested of its parens patriae power ${ }^{16}$ but there have been some questions about the use of the power in a field where there is relevant legislation. While the courts must respect the legislation, they may use their inherent jurisdiction to fill gaps in it. In a

9. Meikle v. Authenac 3 R.F.L. 84 (Alta. S.C. App. Div.); Nelson v. Findlay and Findlay 15 R.F.L. 181 (Alta. S.C.).

10. R.v. Greenhill(1836) 4 AD. \& E. 624.

11. Roughly translated, this is "father of his country" and refers to the once limitless authority of the King.

12. The Supreme Court of Judicature Act, 1873 (U.K.), $36 \& 37$ Vict., c. 66.

13. The Supreme Court of Judicature Act, 1873 (U.K.), 36 \& 37 Vict., c. 66, s. 24.

14. The Supreme Court of Judicature Act, 1873 (U.K.), 36 \& 37 Vict., c. 66, s. 25.

15. See for example, The Judicature Act, R.S.A. 1980, c. J-15, which vests this jurisdiction in The Supreme Court of Alberta.

16. Lutz v. Legal Aid Manitoba 37 A.R. 351 (C.A.). The court follows the Ontario Court of Appeal in Ramsayv. Ramsay (1977) 70 D.L.R. (3d) 415 on this point. 
recent case, ${ }^{17}$ the Supreme Court of Canada used its parens patriae power to grant relief in a particular situation where none was provided by the adoption act in question. ${ }^{18}$

\section{Provincial Legislation}

It is probably not true that all courts enjoy this inherent jurisdiction as was suggested in another Alberta decision, ${ }^{19}$ but jurisdiction in family matters has been conferred on a number of inferior courts by their provincial legislatures. ${ }^{20}$ This vesting of jurisdiction in such matters was approved by the Supreme Court of Canada in Reference Re Adoption $A c t{ }^{21}$ in which it upheld the constitutionality of provincial statutes empowering inferior courts to, among other things, make orders for children in need of protection and grant adoptions.

\section{THE PRINCIPLES DEFINED}

\section{The Doctrine of Parental Rights}

The leading Canadian formulation of the parental rights doctrine is probably Rand J.'s statement in Hepton v. Maat: ${ }^{22}$

... prima facie the natural parents are entitled to custody unless by reason of some act, condition or circumstance affecting them it is evident that the welfare of the child requires that that fundamental natural relation be severed.

Canadian courts have found a wide variety of factors determinative of parental inadequacy sufficient to justify the award of custody to a third party: for example, abandonment of a child; ${ }^{23}$ sexual promiscuity or immorality; ${ }^{24}$ alcoholism or habitual drunkenness. ${ }^{25}$

While it was once true that parental rights were based on the notion of a proprietary interest in children, that is no longer so. Nowadays the parental rights doctrine is applied by the courts on what its critics might call the pretext that to do so is in the interest of the child, the assumption being that a natural parent will, except in extreme circumstances, most satisfactorily fulfil his child's needs; in other words, that there is something inherently valuable to both parents and child in the blood relationship and that the reciprocity of the relation ought to be preserved

17. Beson v. Director of Child Welfare for Province of Newfoundland 39 Nfld. 8 P.E.I.R. and 111 A.P.R. 246.

18. The Adoption of Children Act, S.N. 1972, c. 36, ss. 11, 11A, 11 B.

19. McGeev. Waldern 4 R.F.L. 17, [1971] 4 W.W.R. 684 (Alta. S.C.).

20. See, for example, Provincial Court Act, R.S.A. 1980, c. P-20.

21. [1938] S.C.R. 398, 71 C.C.C. 110, [1938] 3 D.L.R. 497.

22. [1957] S.C.R. 606, 10 D.L.R. (2d) 1 at 1.

23. See, for example, Re MacPherson 9 N.B.R. (2d) 477 where abandonment by the parent was sufficient to justify refusal of custody sought from foster parents.

24. See, for example, Re McLean 31 D.L.R. (3d) 363 where the mother's behaviour, including immorality, was sufficient to justify dispensing with her consent to adoption.

25. See, for example, Re Maloney 12 R.F.L. 167. Here, even when the alcoholic parents had been rehabilitated, the court refused to terminate a guardianship and return the child to them. 
through the protection of the rights of both parent and child. To once again quote Mr. Justice Rand from Hepton v. Maat: ${ }^{26}$

The controlling fact in the type of case we have here is that the welfare of the child can never be determined as an isolated fact, that is, as if the child were free from natural parental bonds entailing moral responsibility, as if, for example, he were a homeless orphan wandering at large.

Thus, by his natural relation to his child, a parent incurs certain responsibilities and his position vis à vis the child will be protected as long as he can and will discharge those duties. The child's interest is protected by the possibility of his placement elsewhere when a parent either cannot or will not provide acceptable care.

\section{The "Best Interest of the Child" Test}

The "best interest of the child" test is based on a similar concern for the child, whose welfare, according to the classic statement of the test is the "first and paramount consideration" 27 to which all others, including the desires of the natural parent, are subordinate. The Ontario Court of Appeal in $\operatorname{Re}$ Moores and Feldstein, ${ }^{28}$ which quickly became Canada's leading case for the best interest test, approved that principle and in so doing followed the House of Lords' opinion in $J v . C .{ }^{29}$

Dubin J.A. for the Ontario court firmly denied the existence of any prior legal rights in a parent to the custody of his children, relying on the opinion of Lord MacDermott, who said that if the welfare of the infant is the first and paramount consideration, ${ }^{30}$

... that means an end of any presumption of law respecting parental rights and wishes so far as the test of welfare is concerned.

Mr. Justice Dubin did not ignore contrary Canadian authorities ${ }^{31}$ which do recognize prior parental legal rights, but he summarily distinguished them by explaining that the restoration of children to their parents in those cases was based not on any rights in the parents but rather, on the obvious benefits to the children. ${ }^{32}$ Again he relied on an English opinion, this time that of Lord Wilberforce in Re Adoption Application 41/61 (No. 2): 33

The tie (if such is shown to exist) between the child and his natural father (or any other relative) may properly be regarded in this connection, not on the basis that the person concerned has a claim which he has a right to have satisfied but ... to the extent that the conclusion can be drawn that the child will benefit from the recognition of the tie.

26. Supran. 8.

27. This is derived from section 1 of the Guardianship of Infants Act, 192515 \& 16 Geo. $5, \mathrm{c}$. 45 but the use of the word "paramount" has been traced back by Lord Upjohn to $\operatorname{Re} A . \&$ B. (Infants) [1897] I Ch. 786 according to Hall, "The Waning of Parental Rights" (1972) 31(1) Cambridge Law Journal 248 at 255.

28. [1973] 3 O.R. 921, 12 R.F.L. 273, 38 D.L.R. (3d) 641 (C.A.).

29. [1970] A.C. 688, [1969] I All E.R. 788.

30. Id. at 714, cited in Re Moores and Feldstein 12 R.F.L. 273 at 284.

31. See, for example, Hepton v. Maat, supra n. 8, and Re Baby Duffell 1950 S.C.R. 737, 1950 4 D.L.R. 1.

32. Re Moores and Feldstein 1973 O.R. 921, 38 D.L.R. (3d) 641, (1974) 12 R.F.L. 273 at $285-$ 286.

33. 1964 Ch. 48 at 53 . 
According to the best interest test, a parent has no independent prior legal rights to custody of his child and there is no presumption in his favour. This means that his wishes vis à vis his child are merely one of the factors which may be considered when the child's best interest is made the first and paramount consideration, which was described by Lord MacDermott as: ${ }^{34}$

... a process whereby, when all the relevant facts, relationships, claims and wishes of parents, risks, choices and other circumstances are taken into account and weighed, the course to be followed will be that which is most in the interests of the child's welfare as that term has now to be understood.

There have been various attempts to establish guidelines of appropriate criteria for determining a child's best interest, ${ }^{35}$ but the multiplicity and complexity of factors make this a difficult exercise. At any rate, there can be no doubt that the test places the child first and all other factors are considered only to the extent that they affect the child.

\section{The Conflict}

Although the primary consideration of both the parental rights doctrine and the best interest test is the welfare of the child, their respective applications may have different consequences. An adequate parent entitled to custody under a parental rights doctrine might be denied custody under the best interest test. One reason is that the principle of parental rights presumes the advantages of parental custody so that parents will only be deprived of their rights if there has been a breach (whether

34. J.v. C. 1970 A.C. 668 at $710-711$.

35. See, for example, K.M. Weiler and G. Berman, "Re Moores and Feldstein - A Case Comment and Discussion of Custody Principles" (1974) 12 R.F.L. 307 where the authors list physical well-being, psychological needs such as affection and stimulation, continuity of relationships, lifestyle, conduct of the parties and stability of the home situations as factors to be considered.

For a statutory definition see, for example, the Ontario Child Welfare Act, R.S.O. 1980, c. 66 s. 1(b):

(b) "best interest of the child" means the best interests of the child in the circumstances having regard, in addition to all other relevant considerations, to

(i) the mental, emotional and physical needs of the child and the appropriate care or treatment, or both, to meet such needs,

(ii) the child's opportunity to enjoy a parent-child relationship and to be a wanted and needed member within a family structure,

(iii) the child's mental, emotional and physical stages of development,

(iv) the ef fect upon the child of any disruption of the child's sense of continuity,

(v) the merits of any plan proposed by the agency that would be caring for the child, compared with the merits of the child returning to or remaining with his or her parent,

(vi) the views and preferences of the child, where such views and preferences can be reasonably ascertained,

(vii) the ef fect upon the child of any delay in the final disposition in the proceedings,

(viii) any risk to the child of returning the child to or allowing the child to remain in the care of his or her parent;

For the most celebrated and controversial discussion of the best interest test see Beyond the Best Interests of the Child by J. Goldstein, A. Freud and A.J. Solnit (1973) in which the authors propose a revised best interest test called the "least detrimental alternative" to minimize psychological damage to children in custody disputes. In a second book, Before the Best Interests of the Child (1979) which appears to be an apology for their first, these same authors recommend guidelines to limit state intervention. 
through fault or not) of concomitant duties, or in extreme circumstances. The best interest test, on the other hand, requires proof of the advantages which are assumed in the parental rights doctrine. As Dubin J.A. stated in Re Moores and Feldstein: ${ }^{36}$

Although in most cases it is to be expected that a child will benefit by the ties of affection of a parent and what naturally flows from it, that must be a question of fact in every case, and I do not think that 1 am bound by precedent to proceed on the assumption that it is inevitably so.

and further, ${ }^{37}$

I conclude, therefore, that it is the duty of the court to view all the circumstances relevant to what is in the interest of the child, including a consideration as to whether the evidence disclosed that the child would benefit from the tie of a child to its mother.

Courts have more than occasionally tried to combine the two principles. A typical formulation is that the natural parents have a prior claim to custody as against the world if it is best for the child. ${ }^{38}$ Another is that the best interest of the child is the important factor but the natural parents are best suited to serve those interests. ${ }^{39}$ In the former, although the parental claim is the nominally important factor, it is a tenuous claim indeed if better prospects elsewhere for the child may defeat it. At first glance the best interest test is the guiding principle in the latter but it is soon clear that the presumption in favour of natural parents is merely another use of the parental rights principle.

The courts must, as Lord Justice Danckwerts suggests, use one principle or the other:40

... I would respectfully point out that there can only be one "first and paramount consideration", and other considerations must be subordinate. The mere desire of a parent to have his child must be subordinate to the consideration of the welfare of the child, and can be effective only if it coincides with the welfare of the child. Consequently, it cannot be correct to talk of the pre-eminent position of parents, or of their exclusive right to the custody of their children, when the future welfare of those children is being considered by the court.

Unless the courts accept that a parent's desires for his child are always in the child's best interest, in other words that the two tests are one and the same (and this is extremely unlikely since it would mean that a child could not be removed from his parents against their will in even the direst of circumstances), only one of the tests can be used at a time.

In Canada, as in other jurisdictions, ${ }^{41}$

[s]ince neither principle has, for historical reasons, been abandoned by most courts, a preference for one has necessarily entailed a corresponding adulteration or weakening of the other. In the majority of jurisdictions it has been parental rights which have been sacrificed, although these rights are almost universally recognized to exist.

36. (1974) 12 R.F.L. 273 at 285.

37. Id. at 287.

38. McKayv. McKay(1977) 26 R.F.L. 252 at 253.

39. Re Baby Duffell[1950] S.C.R. 737 at 747.

40. In Re Adoption Application 41/61 [1963] Ch. 315 at 329, [1962] 3 All E.R. 553 cited in $R e$ Moores and Feldstein 12 R.F.L. 273 at 283-284.

41. V.A. Roeser, "Recent cases, Domestic Relations - Judicial Determination That Grandparents Would Best Serve Interests of Child Supports Award of Custody to Grandparents Rather Than Father, Painterv. Bannister (lowa 1966)" (1967) 4 San Diego Law Review 181 at 185. 
The best interest test, while it probably predominates today, has certainly not entirely defeated the notion of parental rights. The competition between the two was for many years manifested in the courts' various interpretations of the parens patriae power. While all concur that it is a power to act in the interest of the child, they have never agreed whether they may separate parent and child in the absence of parental misconduct or other grievous circumstances. Proponents of the best interest test would argue yes; supporters of parental rights, no. More recently, with the proliferation of laws in the areas of child protection, adoption, and custody itself, the struggle has shifted to the legislation and case law interpretation of it, where both principles are recognized in various and of ten conflicting ways.

\section{SOME BACKGROUND OF THE PRINCIPLES}

\section{A. HISTORY}

\section{English Case Law}

The confusion as regards the two mutually exclusive principles now evident in legislation, has plagued the courts, especially in interpreting their parens patriae jurisdiction, since the late nineteenth century. It is a popular misconception that equity has always applied the principle of paramountcy of the child's welfare, otherwise known as the best interest test. ${ }^{42}$ Recent English research shows quite the contrary; equity recognized parental duties and of ten accorded parents a prima facie right to custody of their children. ${ }^{43}$ In Re Plomley, ${ }^{44}$ for example, Bacon V.-C., held that the court "has no right to interfere with the sacred right of a father over his own child in the absence of a charge of immorality of conduct."

The high water mark of the parental rights doctrine is represented by $\operatorname{Re}$ Agar-Ellis, decided after the courts had merged and the rules of equity prevailed. In this case, the Master of the Rolls, Sir Baliol Brett, adopted Bacon V.-C.'s statement of the law, ${ }^{45}$ while Cotton L.J. expressly rejected the welfare test in holding that "it is not in our power to go into the question as to what we think is for the benefit of this ward." 46 The court refused to interfere with the father in the exercise of his parental authority except where by his "gross moral turpitude" he forfeited those rights or by his conduct abdicated his parental authority. ${ }^{47}$

In the last decade of the nineteenth century, the welfare of the child became the predominant consideration. In $R e$ Gyngall, ${ }^{48}$ the same Master

42. See, for example, Re Moores and Feldstein supra n. 28 at 284 where Dubin J.A. describes $J$. v. C., which stands for the proposition that the welfare of the child is the first and paramount consideration, as an "expression by the House of Lords of what the law presently is and always has been."

43. J.C. Hall, "The Waning of Parental Rights" (1972) 31 Cambridge Law Journal248.

44. (1882) 47 L.T. 283 at 284 , cited id. at 249.

45. (1883) 24 Ch. D. 317 at 328-329, cited by Hall, supran. 43 at 249.

46. Re Agar-Ellis (1883) 24 Ch. D. 317 at 334.

47. Id. at 323 .

48. [1893] 2 Q.B. 232. 
of the Rolls held that the child's welfare is the most important consideration and that a natural parent can be denied custody of his child in the absence of misconduct if it is for the welfare of the child. 49

The opinion of the courts was still not settled, however, and after reverting briefly to the parental rights doctrine in $R$. v. New, ${ }^{50}$ they changed their minds again. In Re Mathieson, ${ }^{51}$ the English Court of Appeal refused to award custody of his daughter to a man who had voluntarily placed her with his brother and his wife when unable to care for her. The Court used the welfare approach and despite a lack of evidence of any misconduct or unfitness on the part of the father, found that to return the child to him would be "injurious to the best interests of the child." 52

At the time of the 1925 passage of the Guardianship of Infants Act, ${ }^{53}$ the courts' preference appears to have been the best interest test. Yet, the debate on the bill in both Houses of the British Parliament is equivocal, as if even at the time there was uncertainty as to how far the welfare principle had encroached on basic parental rights. ${ }^{54}$ One might reasonably presume that the act, which declared that in matters of child custody th. welfare of the child must be the first and paramount consideration, would have settled the matter once and for all. Such was not the case. Just a year later in $R e$ Thain ${ }^{55}$ and again in $R e$ Carroll, ${ }^{56}$ the old doctrine of parental rights apparently reasserted itself. With the former, it has been suggested that this may have been due to a subsequent misunderstanding of the decision, ${ }^{57}$ but in the latter, Slesser L.J. for the Court of Appeal clearly dismissed the Guardianship of Infants Act as irrelevant in a third party case and confined to questions as between the rights of father and mother. ${ }^{58}$

Finally, after another forty years of uncertainty, that interpretation of the statute (and the parental rights doctrine with it) was "laid to rest" 59 in the House of Lords in $J$.v. C. ${ }^{60}$ Their Lordships were of the opinion that section 1 of the Guardianship of Infants Act 1925 (by then Section 1 of the Guardianship of Minors Act 1971) ${ }^{61}$ applied to custody disputes be-

49. Id., at 242-243.

50. (1904) 20 T.L.R. 583 cited in Hall, "The Waning of Parental Rights", supra n. 43 at 250.

51. (1918) 87 L.J. Ch. 445 cited in Hall, "The Waning of Parental Rights", supra n. 43 at 250.

52. Id., at 447 .

53. $15 \& 16$ Geo. 5 , c. 45.

54. Hall, "The Waning of Parental Rights", supran. 43 at 251-252.

55. [1926] Ch. 676 cited in Hall, "The Waning of Parental Rights", supra n. 43 at 253.

56. [1931] 1 K.B. 317 cited in Hall, "The Waning of Parental Rights", supra n. 43 at 253.

57. Hall, "The Waning of Parental Rights," supra n. 43 at 253.

58. [1931] 1 K.B. 317 at 355 cited in Hall, "The Waning of Parental Rights", supra n. 43 at 253.

59. Hall, "The Waning of Parental Rights", supran. 43 at 254.

60. J.v. C. [1970] A.C. 688, [1969] I All E.R. 788.

61. Guardianship of Infants Act, 192515 \& 16 Geo. 5, c. 45, s. 1:

"Where in any proceeding before any court ... the custody or upbringing of an infant ... is in question, the court, in deciding that question, shall regard the welfare of the child as the first and paramount consideration, and shall not take into consideration whether from any other point of view the claim of the father, or at any right at common law possessed by the father in respect of such custody, upbringing ... is superior to that of the mother, or the claim of the mother is superior to that of the father." 
tween parents and strangers. This opinion has been an extremely persuasive authority for use of the best interest test in Canadian third party protection, adoption and custody cases.

In view of its influence in Canada, three points about the case must be noted. First, the court clearly made section 1 of the Guardianship of Minors Act the basis of its decision. The ratio decidendi of the case is that the welfare test of Section 1 governs third party custody cases. Any further elaboration of the test such as Lord MacDermott's interpretation of the phrase "ffirst and paramount" is purely obiter. ${ }^{62}$ The House of Lords, which is not bound by any court beneath it or by its own previous decisions, was presented with two strong, opposed lines of case law and might easily have approved, in the exercise of its parens patriae jurisdiction, either the principle of parental rights or the best interest test; and might have done so without relying on the Guardianship of Minors Act, the preamble of which appears to indicate that it was meant to be confined to questions as between the mother and father. ${ }^{63}$ Nevertheless, their Lordships chose the statute.

Second, despite their denial that the interest of the parents is anything more than one factor in many to be considered in predicting the course of best interest for the child, their Lordships felt obliged to dwell at considerable length on the conduct of the natural parents. While maintaining that the claim of the parents is, like all other factors, only evidence relating to the child's welfare and of no independent significance, they seemed reluctant to part altogether with the concept of prior parental rights. Lord MacDermott, for example, said: ${ }^{64}$

While there is now no rule of law that the rights and wishes of unimpeachable parents must prevail over other considerations, such rights and wishes . . . can be capable of ministering to the total welfare of the child in a special way, and must therefore preponderate in many cases.

This rather ambiguous statement leaves room for argument that their Lordships did not intend to abandon entirely a presumption in favour of parents.

Third, the unusual facts of this case and the child's lengthy stay with the foster parents are sufficient to distinguish it from the majority of third party custody cases. The child's Spanish parents placed him with English foster parents with whom he spent nearly ten years. Not surprisingly, by the time the case reached the House of Lords he had become fully integrated with the English way of life and with the foster family in particular. The length of custody alone rendered it absurd to uproot the child and place him in a family of virtual strangers in a strange land. The difficulty their Lordships faced was the unimpeachability of the natural parents. Far from misconducting themselves or abandoning their child in the usual sense, they had shown the utmost concern for him by giving

62. J. v. C. [1970] A.C. 688 , infra, n. 34 .

63. The preamble to the Guardianship of Infants Act reads:

"Whereas Parliament by the Sex Disqualification (Removal) Act, 1919, and various other enactments, has sought to establish equality in law between the sexes, and it is expedient that this principle should obtain with respect to the guardianship of infants and the rights and responsibilities conferred thereby:"

64. J. v. C., supra n. 60 at 715 . 
him to foster parents who could better provide for his needs. Here, it is respectfully submitted that their Lordships, rather than relying on the best interest test, might instead have applied a parental rights doctrine such as Rand J.'s in Hepton v. Maat. ${ }^{65}$ It will be recalled that His Lordship recognized prior parental rights but allowed that these might be lost where because of some act, condition or circumstance affecting them, the welfare of the child requires that that fundamental natural relation be severed. Surely this was such a case.

\section{Canadian Case Law}

Historically, the Canadian case law contains the same confusion and disagreement as its English parent. Most decisions in the years from the 1880 's to the 1930's concerned private custody matters, many arising from private adoption arrangements. There are few reported child protection cases and most of those concern parental efforts to regain custody of children who had been in care. The courts were unable to agree whether parental rights or the child's interest ought to be the main consideration and sometimes confused the two. In Re Ferguson, for instance, ${ }^{66}$ the court refused the petition of the father and held that his superior rights should be considered suspended in the best interest of his child.

In the 1890's, parental rights seem to have had the upper hand and in $\operatorname{Re}$ Hatfield, ${ }^{67}$ it was held in a custody case that the habits and character of the father must be open to the gravest objection to defeat his entitlement to his child. In an adoption case, Farrell v. Wilton, ${ }^{68}$ it was held that the father has a right to take back the child at any time. By the early 1900's, this trend had ended and the best interest test again predominated. In 1908 in $R e$ Longaker, ${ }^{69}$ the Ontario Court of Appeal affirmed that the welfare of the child is paramount and the cases in all three types of disputes through to the 1920's reflect this view. In fact, Middleton J. of the Ontario Court of Appeal considered the law to be quite settled, and confidently asserted: ${ }^{70}$

In all the law relating to the custody of children, the true welfare of the child is being ever more clearly written as the fundamental axiom to which all other considerations must, in the end, yield.

That was in 1922. Ironically, just when the English Guardianship of Infants Act was proclaimed, the Canadian courts entered a brief period of recognizing parental rights. Several decisions from the mid and late 1920 's indicate this revival, although there are exceptions and neither principle seems to have predominated. In Re Mackay, ${ }^{71}$ for example, the court held that the natural parents have a prima facie right to custody and that before a parent may be deprived of that right there must be some

65. [1957] S.C.R. 606, 10 D.L.R. 1 at 1 .

66. (1881) 8 P.R. 556.

67. (1895) 1 N.B. Eq. 142.

68. (1893) 3 Terr. L.R. 232.

69. (1908) 12 O.W.R. 1193. Af firmed 14 O.W.R. 321 (C.A.).

70. Re Steacy (1923) 52 O.L.R. 579 (C.A.).

71. [1923] 3 W.W.R. 369 (Man.). 
definite and clear reason why it would be against the child's best interest. But in $\operatorname{Re}$ Chiemelewski, ${ }^{72}$ a child protection case, it was held that the court must contrast the situation in the foster home with the real home and that is not the same as requiring a finding of unfitness of the natural parents.

In the few reported decisions of the 1930's and 1940's, the best interest test was more popular but there were still parental rights decisions. In an Alberta case, $S$. v. $S .{ }^{73}$ the grandparents were awarded custody against the mother's will in view of the welfare of the child. Similarly, in Platz v. Lear ${ }^{74}$ the child was left with grandparents because her interests were incomparably better served there than with her father. In $\operatorname{Re} J o h n s o n,{ }^{75}$ the foster parents had only to show with reasonable clarity that it was in the best interest of the child for him to be placed other than with the parent. They were not required to show unfitness in the parent. However, in $R e$ Thompson ${ }^{76}$ the court held that the father's prima facie right was not to be interfered with in the absence of evidence that he was unfit and an improper person to have charge of his child.

It is obvious that up until the 1950's there was no real agreement on which principle to apply. Then the Supreme Court of Canada handed down two important decisions in which it emphasized the prior rights of parents. The first was Re Duffel: Martin v. Duffell 77 in 1950 and the second, Hepton v. Maat ${ }^{78}$ in 1957, discussed earlier in this paper. Apparently, however, the lower courts paid little attention to these very clear statements of the law. In the 1960's and 1970's, many of them insisted on applying the best interest standard in all types of disputes and to this day they seem divided on the question of the proper test.

The 1973 decision of the Ontario Court of Appeal in Re Moores and Feldstein 79 became the most controversial and influential of the best interest decisions but it is respectfully submitted that not only did it fail to follow the Supreme Court authorities; it depended on a mistaken interpretation of the English law. Dubin J.A. said: ${ }^{80}$

Unlike the common-law courts, the court of Chancery with its broad power to do equity placed, with few exceptions, the welfare of the child as the paramount consideration in determining custody matters to which all else had to give way, including the wishes of the parent, if the court felt that it was in the welfare of the child to be with others.

Hall's analysis, summarized earlier in this paper, shows that this is not, strictly speaking, correct. Equity was of ten prepared to recognize the prior right of parents and while always acting in the interest of the child,

72. 61 O.L.R. 651, [1928] 2 D.L.R. 49.

73. [1941] 1 W.W.R. 205 (Alta.).

74. [1936] 3 W.W.R. 464 (Alta.)

75. Re Johnson: Johnson v. Hall, (1930) 43 B.C.R. 328 (C.A.).

76. (1935) 10 M.P.R. 36 (P.E.I.).

77. [1950] S.C.R. 737, [1950] 4 D.L.R. 1.

78. [1957] S.C.R. 606, 10 D.L.R. (2d) 1.

79. 12 R.F.L. 273 (Ont. C.A.).

80. Id., at 281 . 
it did not always place that interest above the rights of the natural parents. Dubin J.A. also said: ${ }^{81}$

I do not read the judgment of the House of Lords in the case of J.v. C., supra, as being dependent on the language of s. 1 of the Guardianship of Infants Act, 1925, but as an expression by the House of Lords of what the law is presently and always has been.

Again, it has been shown that the law has not always made the interest of the child the first and paramount consideration. In fact, even after proclamation of the Guardianship of Infants Act, many courts continued to recognize the prima facie rights of natural parents to the custody of their children and the decision in J.v. C. ${ }^{82}$ was indeed dependent on a finding that that Act applied to third party cases. In addition, it should be noted that at the time of $R e$ Moores and Feldstein, Ontario had no act comparable to the British legislation.

Since the Moores \& Feldstein ${ }^{83}$ decision Canadian courts have remained divided on which principle to apply. In More v. Primeau, ${ }^{84}$ the Ontario Court of Appeal reaffirmed the application of the best interest test to third party custody disputes but recent lower court decisions in Ontario interpreting child protection legislation have shown more support for parental rights. ${ }^{85}$

In Alberta, the Court of Appeal continues to apply the parental rights test in third party custody cases, most recently in Lutz v. Legal Aid Manitoba ${ }^{86}$ which impliedly reaffirmed its earlier decision in Meikle v. Authenac. ${ }^{87}$ The lower courts have shown more interest in the best interest test than the Court of Appeal. In Nelson v. Findlay, ${ }^{88} \mathrm{McDonald} \mathrm{J}$. in reviewing various authorities quoted at length and with approval from Re Moores and Feldstein, ${ }^{89}$ and proceeded to determine the best interest of the child by comparing the merits of the competing claimants. In Lawrence v. Lawrence, ${ }^{90}$ where the dispute was between the mother and a grandmother, White Prov. J. followed Re Moores and Feldstein, ${ }^{91}$ McGee v. Waldern, ${ }^{92}$ which is a 1971 Alberta Supreme Court decision based on the best interest test, and Nelson v. Findlay. ${ }^{93}$ Thus, despite the contrary authority of the Supreme Court and of their own Court of Appeal the lower courts have insisted on using the best interest test.

The question of which is the proper test will continue to plague the courts until the provinces legislate a uniform standard. Even another

81. Id., at 284.

82. [1970] A.C. 688, [1969] 1 All E.R. 788.

83. [1973] 3 O.R. 921,12 R.F.L. 273, 38 D.L.R. (3d) 641 (C.A.).

84. (1977) 2 R.F.L. (2d) 254.

85. E.g., Re Catholic Children's Aid Society and Pamela M. (1982) 36 O.R. (2d) 451, Re T.H. et al and Catholic Children's Aid Society of Metropolitan Toronto(1981) 35 O.R. (2d) 151.

86. Lutzv. Legal Aid Manitoba 37 A.R. 351 (C.A.).

87. 3 R.F.L. 84 (Alta. S.C. App. Div.).

88. 15 R.F.L. 181 (Alta. S.C.).

89. [1973] 3 O.R. 921, 12 R.F.L. 273, 38 D.L.R. (3d) 641 (C.A.).

90. (1978) 5 Alta. L.R. (2d) 231 (Fam. Ct.).

91. [1973] 3 O.R. 921, 12 R.F.L. 273, 38 D.L.R. (3d) 641 (C.A.).

92. 4 R.F.L. 17, [1971] 4 W.W.R. 684 (Alta. S.C.).

93. 15 R.F.L. 181 (Alta. S.C.). 
Supreme Court decision is unlikely to settle the matter since that Court's decisiveness is undermined by the lower courts' remarkable disrespect for precedent. In $R e$ Moores and Feldstein ${ }^{94}$ for example, the Ontario Court could have reached the same result if it had followed Mr. Justice Rand in Hepton v. Maat ${ }^{95}$ and found that the mother, by her behavior which was certainly less than exemplary, had forfeited her prima facie right to custody of her daughter. Instead, the court, eager to apply the then ascendent best interest test, ignored the law as laid down by the Supreme Court in previous cases.

\section{B. CURRENT LEGISLATION}

\section{Child Protection}

Both the best interest and parental rights principles are recognized in various ways by legislation under which child-centred disputes may arise. The incorporation of the best interest standard into the laws on adoption, child protection and custody has meant the emasculation of parental rights. Still, despite the popularity of the best interest standard since the late 1950's and early 1960's, the principle of parental rights has survived and is now enjoying a revival.

All provincial child protection acts give parental rights some protection. Some, such as Alberta's Child Welfare Act, do so by allowing apprehension of a child only where he or she is found to be neglected and therefore in need of protection. ${ }^{96}$ Even then, the wording of the act allows the courts considerable latitude to define just what constitutes neglect. A loose interpretation of the act would permit removal of a child in a wide range of circumstances and according to such fuzzy concepts as "endangered emotional or mental development." 97 The Alberta courts, however, have read the neglect sections strictly, thereby protecting parental rights except in situations of grave misconduct. ${ }^{98}$

Many other provincial child protection acts have similarly worded sections, ${ }^{99}$ but more liberal interpretations by the courts have allowed removal when parental behaviour does not amount to abuse ${ }^{100}$ or neglect. ${ }^{101}$ Even when parental unfitness or misconduct is a criteria for removal, the best interest test may be applicable when parents seek a return of their child by termination of a guardianship, for example. ${ }^{102}$ Then the parents must prove not only that they are fit to receive and care for their child, but that the child's return is in his best interest. ${ }^{103}$

94. [1973] 3 O.R. 921, 12 R.F.L. 273, 38 D.L.R. (3d) 64 1 (C.A.).

95. [1957] S.C.R. 606, 10 D.L.R. (2d) 1.

96. E.g., Child Welfare Act, R.S.A. 1980, c. C-8, s. 6(a).

97. Child Welfare Act, R.S.A. 1980 c. C-8, s. 6(e)(xi).

98. Re Grant and Grant (1972) 15 R.F.L. 9 (Dist. Ct.).

99. E.g., Children's Services Act, Consolidated S.N.S. c. C-13, s. 2(m)(iv).

100. E.g., Minister of Social Services v. M.W. (1981) 49 N.S.R. (2d) 448 (Fam. Ct.).

101. E.g., Re Brown 9 O.R. (2d) 185 (Co. Ct.).

102. Child Welfare Act, R.S.C. 1980, c. 66, s. 38(1). This section allows the court to terminate a wardship in the best interests of the child and s. 32(4) allows for the termination of a supervisory order in the best interests of the child.

103. E.g., R. v. Family and Children's Services of Annapolis County 50 N.S.R. (2d) 316 (S.C. App. Div.); M.M. v. B.M. et al. 37 O.R. (2d) 716 (C.A.); affg. 37 O.R. (2d) 120. 
Some provinces have recently given increased recognition and protection to parental rights by requiring the courts to consider various possibilities for caring for a child in need of protection and to leave the child with his parents under a supportive care order if at all possible. ${ }^{104}$ This alternative to institutional or foster care recognizes both that the child needs protection and that the family, while it needs help, is worth preserving.

The legislatures of some provinces have confused the use of the two principles by adding to their child protection legislation a general proviso that in any action under the act, the welfare of the child is the paramount consideration ${ }^{105}$ or that the safety and well-being of the child is paramount. ${ }^{106}$ Exactly where these leave the parental rights which were supposedly protected by other sections of the acts is unclear.

\section{Adoption}

The two principles also come into conflict in the consent sections of adoption legislation. All provincial adoption laws require parental consent before an adoption order can be granted but the circumstances in which they allow dispensation of that requirement vary considerably. In some provinces, the court can only waive it where there has been abandonment, neglect or similar parental misconduct. ${ }^{107}$ Another requires only unjustifiable refusal of consent ${ }^{108}$ and still others go much further and will dispense with parental consent if it is in the best interest of the child, and even if it is not unreasonably withheld. ${ }^{109}$

As with child protection legislation, the effect on the consent provisions of a general proviso making the best interest of the child the standard for all actions under the act is unclear.

\section{Private Party}

The patchwork of provincial legislation precludes generalization except to say that the law, when viewed as a whole, is confusing. All provinces have legislation by which a parent or other person may be awarded

104. E.g., Child Welfare Act, R.S.O. 1980, c. 66

S. 30(4) is a new provision which specifically empowers a judge to impose reasonable terms and conditions on the custodial person, the supervising society or the child.

S. 30(5) requires that the court in determining what order to make for the child shall enquire of the parties whether efforts were made to assist the child while the child was in the care of his parents or other person before the child came into the care of the society.

S. 36(d) requires a statement of the court's reasons where it authorizes removal of a child or a refusal to return the child and these reasons must include reasons why the child cannot be adequately protected without removal or without the refusal.

105. E.g., Children's Services Act, Consolidated S.N.S. c. C-13, s. 76:

"In any action taken under this Act the court shall apply the principle that the welfare of the child is the paramount consideration."

106. E.g., Family and Child Service Act, S.S.C. 1980, c. 11, s. 2:

"In the administration and interpretation of this Act the safety and well being of a child shall be the paramount considerations."

107. E.g., Child Welfare Act, R.S.A. 1980, c. C-8, s. 50(5).

108. E.g., Adoption Act, R.S.Q. 1977, c. A-7, s. 23.

109. R.S.A. 1980, c. D-37. 
custody of a child and many, like Alberta, have more than one act which applies in private party disputes. In Alberta, the Court of Queen's Bench under Part VII of the Domestic Relations Act ${ }^{110}$ (which also preserves this court's equitable jurisdiction) and the Family Division of the Provincial Court under the Provincial Court Act, Part 3,111 both deal with custody matters. The former Act requires the court to have regard to the welfare of the minor and the conduct of the parents but does not require the court to act in the child's best interest. In the latter, the court must have regard to the best interests of the child, which is not necessarily to make it the "first and paramount consideration". No mention is made of parental conduct or rights. Both leave room for the courts to apply the principle of their choice and there is no guarantee that they will consistently apply one or the other in third party cases.

\section{CRITICISM AND RECOMMENDATIONS}

\section{A. CRITICISM OF THE BEST INTEREST TEST}

\section{Inherent Weaknesses}

In many third party custody cases and especially in those in which the state is a third party, the issue is more than the placement of a child; it may be characterized as a conflict between society's concern for the welfare of individual young members on the one hand and its interest in the preservation of family integrity on the other. Most academics and many courts and legislators seem to think that the best interest test of fers the best protection for children and do not consider it desirable to balance their interest in the child against the benefits to society itself of attempting to strengthen the family unit by counseling its adult members. It has been said for example, ${ }^{112}$

Few would disagree that the best interest rule provides a proper legal framework for judicial analysis of child placement decisions: the needs of the child should take precedence over the biological birthright of the parents when the two conflict.

This preoccupation with the child may be a consequence of the influence of psychological theories of development on legal thinking as indicated by statements such as the following: ${ }^{113}$

The parental rights doctrine has become an anachronism in light of current psychological knowledge. Since it appears that blood may not necessarily be thicker than water, the assumption that a child's best interests will be served by his parents becomes meaningless.

This is at the expense of troubled parents for whom the possibility of rehabilitation is considered remote.

At any rate, the overwhelming endorsement of the best interest doctrine by academic lawyers has been punctuated by only an occasional

110. R.S.A. 1980 , c. D-20.

111. E.g., Child Welfare Act, R.S.O. 1980, c. 66, s. 69(7), see infra n. 25.

112. "Note: In the Child's Best Interest: Rights of the Natural Parents in Child Placement Proceedings" (1976) 51 New York University Law Review, 446 at 449.

113. L.S. McGough and L.M. Shindell "Coming of Age: The Best Interest of the Child Standard in Parent-Third Party Custody Disputes" (1978), 27 Emory Law Journal, 209 at 243. 
dissident voice, among them one who wrote in 1942, long before the best interest test had reached its current popularity:114

Courts and legal rulers alike seem so pleased with themselves in hitting on the bestinterests-of-the-child test, that they are both unable and unwilling to think of anything else...

[In Chapskyv. Wood] [w] ith evident relish, the court repudiated the former rule which af firmed the parents' primary right to custody, and, having rejected this, luxuriated in the solemn self-righteousness of applying the best interest test against all comers.

It is submitted that this observation is even more pertinent today than it was in 1942. The dearth of critical analysis of such a widely used doctrine as the best interest test indicates an assumption by jurists that its merits are obvious to anyone.

Certainly one reason for its popularity is that the principle of primary parental rights is identified with the theory that children are property, a notion which most people find abhorrent. They regard the best interest test as a necessary alternative to the oppressive, even Draconian rule that parents enjoy some sort of proprietary rights in their children. This view is reflected in the case law. In McGee v. Waldern ${ }^{115}$ for example, the court held that a parent has no right to the custody and care of a child, "as he would of a chattel" and that a parent's right is to be considered only to the extent that it is in the best interest of the child.

But the parental right doctrine need not be predicated upon a proprietary interest in or ownership of children. It is arguable that parents have "defensible moral and legal rights to the companionship and rearing of their children which are quite distinct from the chattel theory." 116 Quite apart from ownership, surely a parent does have some special or prior rights to the companionship and love which a child can and will give whether or not the parent is an ideal or even a satisfactory one.

Our society seems to recognize such rights; if it did not then there would be no reason, except as a matter of convenience, for placing a newborn with his parents rather than with those who could best serve his interests. If parents enjoy such rights at a child's birth, how is it that they do not when a dispute over the child arises, unless they have somehow forfeited them? When viewed this way, the problem seems not whether or not parents have prior rights, for it would appear that they do, but when and in what circumstances these are lost or subordinated to the interests of the child.

The main failure of the best interest test is that in its preoccupation with the child it fails to recognize these rights of the parents. As Professor B.D. Inglis, author of a New Zealand family law text, said in a 1973 address: ${ }^{117}$

It is perhaps too easy to treat the child as the central figure. It is easy to forget that the relationship between a child and its parents is a mutual and reciprocal matter and that parents have rights as well as the child.

114. Sayre, "Awarding Custody of Children" (1941-42), 9 University of Chicago Law Review 672.

115. 4 R.F.L. 17, [1971] 4 W.W.R. 684 (Alta. S.C.).

116. V.A. Roeser, “Recent Cases; Painterv. Bannister", supra n. 41 at 188.

117. B.D. Inglis, "The Family, The Law and The Courts" (The Victoria University of Wellington, 1973) at 11-12. 
It is as if the courts really do seem unable to think of anything else except the child. In a recent Ontario child custody case, for example, the court purported to examine the rights of the father who refused to consent to the adoption of his child, but this examination consisted almost entirely of an analysis of what the father would do in the future for the child if his refusal to consent was upheld. ${ }^{118}$ This would seem to be a confusion of parental rights with duties and of what the child might give with what she might receive.

It is submitted that a test which recognizes the mutuality and reciprocity of the parent-child relationship is more conducive to the maintenance and strengthening of the family unit by concentrating on the benefits derived by both parties from such a relationship. The parental rights test does this by holding that a parent has rights which are lost only when concomitant duties are breached. In other words, parents have rights to fulfill duties to their children and in turn receive a child's love and affection; rights they lose if they clearly fail in the exercise of those duties for whatever reason or in other exceptional circumstances. The best interest test on the other hand does not concern itself with the question of what benefits might accrue to the parents (and in turn the family and society) but only with what they must give and the child receive.

The second major fault of the best interest test is that it is indeterminate and arbitrary. This is the result of the predictive nature of the test which compels the court to consider and resolve disputes in a manner quite different from traditional adjudication. In most cases, the courts make findings of fact with regard to past acts or events and then apply the law to these facts. In the best interest test, they must try to predict the future. ${ }^{119}$ Since their decisions will change the legal and personal relationships amongst the parties, they must predict how these changes will affect the behavior of the parties and structure their decisions accordingly. They may consider past acts in this predictive process, but these acts are not determinative of the eventual decision.

Coupled with this predictive aspect is the fact that courts must compare the worthiness of competing parties for custody ${ }^{120}$ and in using the best interest test, evaluate these parties as whole human beings. In fact, it has been argued that a necessary corollary to the best interest test is a "comparative fitness test", by which the qualities of the respective claimants are evaluated to determine which placement will best serve the interests of the child. 121

Precedent and authority are of limited relevance where the decisions are based on an overall evaluation of the competing claimants, often based mainly on their testimony and courtroom demeanor rather than on their previous behavior judged according to specific legal standards. Thus, appellate review is usually limited to cases where the general principles applied by the court are called into question. ${ }^{122}$

118. W.A.v. W.B. (1981) 34 O.R. (2d) 716 at 735.

119. Id.

120. E.g. Nelson v. Findlay 15 R.F.L. 181 (Alta. S.C.) at 194-196.

121. V.A. Roeser, "Recent Cases; Painterv. Bannister", supra n. 41.

122. E.g., Wirth v. Young (1974) 18 R.F.L. 316 (C.A.); Re Moores and Feldstein 12 R.F.L. 273 at 280 . 
It has been suggested that three factors combine to make this predictive and comparative process indeterminate. ${ }^{123}$ First, judges rarely have sufficient information about the parties to predict how they will interact with the child in the long run and are of course unable to predict events which may effect them.

Second, their predictions for the child based at least partly on evaluation of the claimants are very uncertain, because there are a number of theories of human development which they might apply to determine which course would be better for the child. It is generally agreed, however, that no one psychological theory alone is capable of generating reliable predictions.

Third, even if a court could predict possible outcomes by applying developmental theories to the characteristics of the claimants and the care they would provide, there is no set of values by which to determine which outcome would be in the child's best interest. That determination depends on the purposes and values of life itself and society certainly provides no concensus.

\section{Negative Social Implications}

In addition to the inherent shortcomings of the best interest test, there are undesirable societal effects. The first of these is that the test increases the possibilities of destructive state intervention in the family. One of the aims of the modern state is an improvement in the quality of life of its citizens. This goal applies to children as well as to adults. Any efforts on behalf of the state to improve the lives of its individual members necessarily involve some interference with the family unit which traditionally ministers to the needs of its members.

Intervention by the state is facilitated by the best interest test. At three stages in a child protection dispute, it operates to the advantage of the interventionist state and of ten to the detriment of the family (and therefore possibly to the state in the long run). At the initial removal stage, social workers often justify their actions by arguing that they are in the child's best interest. Both the wide statutory definitions of "neglected child" and "child in need of protection" and the statutory best interest test allow them wide discretion in deciding whether to remove children from their families.

This discretion, combined with the fact that removal is often, in the short run, the path of least resistance, encourages removal which is of ten simpler than to undertake continuing efforts to rehabilitate the family itself through supportive services such as family counselling, daycare and visiting homemakers. This is true even though support services are usually less expensive than substitute care. Clearly, substitute care is appropriate in many cases but it is of ten a second best measure used because the resources which a family needs are not provided by the welfare system.

123. R. Mnookin, "Child Custody Adjudication: Judicial Functions in the Face of Indeterminacy" (1975), 39 No. 3 Law and Contemporary Problems 226 at 260-261. 
Not only do workers remove children in what they believe are the childrens' best interests but they believe that it is the role of the court when removal is contested to hear the evidence on both sides and decide according to the best interest test. ${ }^{124}$ This is a misconception since many acts, Alberta's included, authorize child protection decisions to be made by a parental rights test rather than a best interest one. When child welfare workers are under a wrong impression of what the law is they will, if their actions are contested, eventually come into conflict with it. ${ }^{125}$ If their actions are not questioned, they will continue to remove children when unauthorized at law and the families affected by their decisions will remain in most cases, ignorant of this fact.

At the second stage, a judge who is called to adjudicate a custody matter according to a best interest test faces similar difficulties to the child care worker. He may easily underestimate the situation from which the child has been or might be removed and overestimate the advantages of substitute care. Often, it does not require a very generous abstraction of the possible substitute care to improve upon the grim realities of a child's family life. However, especially in child protection cases, the alternatives may not really be all that much better. In fact, they are often worse. In addition, a judge might be tempted to use the best interest test to rationalize a decision regardless of the grounds on which it was really made. The more objective parental rights doctrine, requiring evidence of real misconduct which must be carefully assessed by the court, leaves much less room for class, racial, philosophical or any other bias. ${ }^{126}$

Finally, at the third stage, once a court has approved removal of a child under a best interest test, there is no guarantee that the welfare system will continue to work in his interest. If there is no mandatory periodic judicial review of his situation, there is no guarantee that removal will have been in the best interest at all. This is especially unfortunate in child protection cases where many children placed in foster care temporarily are never returned to their parents and spend their childhood in the limbo shuttling from one foster home to the next.

124. In the Best Interest of the Child, A Report by the National Council of Welfare on the Child Welfare System in Canada, December 1979 at 13.

125. E.g., Re Catholic Children's Aid Society and Pamela M. (1982) 36 O.R. (2d) 451. Nasmith Prov. J. said that the way in which the Children's Aid Society had conducted the case indicated that there was a wide difference between the court and the society regarding the appropriate parameters of society's power to remove children from their families.

126. The notorious Painter v. Bannister 140 N.W. 2d 151 (Iowa 1966) case is an example of a court, while purporting to act in the best interest of the child, actually falling into the trap of philosophical bias. The court compared or, rather, contrasted the grandparents' "'stable, dependable, conventional, middle-class, middlewest background with the "unstable, unconventional, arty, Bohemian, and probably intellectually stimulating household of the father." The court awarded custody to the grandparents and in so doing deprived the natural father of a child he had placed temporarily with the maternal grandparents when distraught over the death of his wife and other child. This case has been heavily criticized in the United States (see for example B.S. Berger, Notes - "A Fit Parent May Be Deprived of Custody of His Child If the Best Interest and Welfare of the Child Would Be Served by Allowing Another Person to Raise Him" (1966-67) Houston Law Review 131 and V.A. Roeser, "Recent Cases; Painter v. Bannister", supra n. 41) but has been cited with approval in at least one Canadian case, Nelson v. Findlay 15 R.F.L. 181 (Alta. S.C.). 
Meanwhile there is often little or no improvement in the family situation from which the child was removed. Perhaps the motivation to assist him is really gone once the child has been removed. In a National Council of Welfare Report, it was admitted that while in theory the system is supposed to work towards the reunification of parents and children in care wherever possible, in practice few if any resources are available to help parents cope with the emotional consequences of separation and overcome the problems which led to the family breakdown. It said:127

While the child welfare system devotes the bulk of its resources to children in care and
their substitute parents, in the majority of cases it is natural parents' problems which
force the children into care in the first place.

There are some supportive services for helping families look after their children, but once the interest of the child has been secured, in theory at least, natural parents of ten do not receive the help they need in order to regain custody of the child.

A second serious implication of the best interest standard is that its vague and discretionary nature encourages litigation because of the uncertainty of outcome it injects into custody cases of whatever variety. Otherwise unlikely litigants are prepared to suffer the anguish and expense of a court action when there is no presumption in favour of either party and each has an equally good chance to win. Litigation which can drag on interminably through hearings and appeals is often as traumatic for the child as for the parties to the action for whom it often exacerbates feelings of bitterness, inadequacy and frustration.

The fact that there is great uncertainty in outcome and that like cases are not decided alike means that the law which in general should indicate what is acceptable parental behavior and what is not, cannot be a reliable guide to parents, custodians or anyone involved in child custody cases. When predictability is sacrificed to the notion that a judge should always decide on the merits of the competing parties, they cannot depend on the fact that certain actions will produce certain results or consequences. They cannot know, for example, just what factors will prompt a judge to find that someone else would be a better custodian for their child or that their consent to an adoption may be waived. ${ }^{128}$ The law then can provide

127. In the Best Interest of the Child, A Report by the National Council of Welfare, supra n. 122 at 15 .

128. Three recent Ontario decisions illustrate this point. All concern s. 69(7) of the Ontario Child Welfare Act R.S.O. 1980 c. 66, which permits dispensation of consent where it is in the best interest of the child.

In H. \& H. v. M. (Adoption) 18 R.F.L. (2d) 138 (Ont. Prov. Ct. Fam. Div.) it was held that s. 69(7) makes it proper to dispense with parental rights when those rights could be terminated in protection proceedings, that is, when there has been parental misconduct. The best interest of the child in adoption proceedings goes beyond the test applied in custody matters.

In W.A.v. W.B. 34 O.R. 716 (2d) (Prov. Ct. Fam. Div.) the court held that parental rights remain an important factor, but only one factor in the assessment of the child's best interest which is the sole test in dispensing with consent. The child's best interest may require a severance of parental rights where the natural parent has arguably been rather consistently involved with the child and has appropriately conducted himself.

In W. v. C. 35 O.R. (2d) 731 (Prov. Ct. Fam. Div.) it was held that even where the father had not misconducted himself or abandoned the child and it was reasonable for him to withhold his consent, that consent may be dispensed with in the best interests of the child. 
neither certainty of outcome nor guidelines for behavior, both important functions of any legal system.

\section{Some Consequences for Individuals}

There are, of course, many unfortunate consequences of the best interest test for individuals involved in third party custody disputes. Included among them are the fact that more parents will lose custody than receive help; more parents who voluntarily place their children in someone else's care will lose custody permanently; parents who ought to make use of substitute care will decline to do so rather than risk losing their children, while children who are placed elsewhere will suffer the indignity of knowing that the world at large views their parents as failures whether the dispute is state or private and especially if the case attracts publicity as they are wont to do. ${ }^{129}$

\section{B. RECOMMENDATIONS}

\section{Child Protection}

In view of the various shortcomings of the best interest test, it is proposed that the provincial legislatures and courts with jurisdiction in family matters adopt improved parental rights tests in protection, adoption and private party custody cases. Where the dispute involves the state in one form or another, the standard ought to limit state intervention of a destructive nature. This could be accomplishd by requiring a real and immediate danger to a child's health before removal from the parents is possible. The threat to the child must be shown by previous dangerous behavior and must not be founded merely on a prediction of future events.

Second, the standard should require that before a child may be removed the state must satisfy itself that the parents and the court if the parents contest removal, that there are no other practical means by which the state can protect the child and help the family. The impossibility of removal in marginal cases and the burden on the state to prove that removal is the only means for protection would encourage the use by the state of family support programs, reducing not only the hardship to families but the cost of the welfare system.

\section{Adoption}

In adoption cases when the issue is consent, there is more than mere custody at stake. If a parent's right to consent is dispensed with and the adoption order approved, he loses all legal rights vis a vis the child; he is no longer a parent of the child. In view of that fact plus the fact that a child may become a de facto member of another family even when his natural parents' legal rights are preserved, those rights ought to be especially well protected. This may be done by requiring a finding of misconduct or some other forfeiture of those rights, but not by allowing the court to dispose of the rights in the best interest of the child.

129. Supran. 2. 


\section{Private Party}

In private party disputes where there is no need to limit state power, the main concern is that parental rights not be completely subordinated to the child's best interest as the court perceives it. If the legislatures and courts are not willing to use a parental right doctrine by which they could still find in favour of the third party in many cases where they now rely on the best interest test, then perhaps they will accept the following modified best interest test by which parental rights are not completely lost. It is this: a child should be in the custody of his parents if there is no difference in which placement is in his best interest or if the prediction that his interests will be better served elsewhere is a highly speculative one. Therefore, unless there is a very high degree of certainty that the child will be better off with the third party, he should be placed in the custody of his parents.

\section{CONCLUSION}

The best-interest standard in settlement of third party custody disputes has in recent years enjoyed increasing recognition in legislation and by courts in the exercise of their parens patriae jurisdiction. It is used both in disputes arising from government intervention and in private party cases. In view of the fact that the leading and most influential Canadian case in favour of the best interest test, Re Moores and Feldstein, ${ }^{130}$ is based on misinterpretations of English common law up to and including $J$. v. C. ${ }^{131}$ and that the use of test has undesirable implications for society as a whole and unfortunate consequences for parents of troubled families in particular, it is recommended that the test be dropped for all childcentred disputes involving the state and replaced by a parental right test to encourage family support rather than substitute care. For private party disputes, a modified version of the best interest test is suggested to offer more protection for natural parents. It is submitted that these proposed standards recognize the interests of both parents and children and in so doing encourage the stability and protect the integrity of the family.

130. [1973] 3 O.R. 921, 12 R.F.L. 273, 38 D.L.R. (3d) 641 (C.A.).

131. [1970] A.C. 688,19691 All E.R. 788. 